\title{
Relationship Between Physical Activities and Emotional Mental Health on High School Students in 2018
}

\author{
Deddy Whinata Kardiyanto ${ }^{1}$, Taufik Ismail ${ }^{2}$ \\ $\left\{\underline{\text { Deddywhinata@staff.uns.ac.id }}^{1}\right.$ taufikismail.ior35@student.uns.ac.id $^{2}$ \}
}

Faculty of Sports, Sebelas Maret University, Surakarta, Indonesia

\begin{abstract}
This study aims to determine the relationship between physical activity and emotional mental health in Indonesia's high school students in 2018. This research is a type of correlation research with two variables, physical activity and emotional mental health. The research was carried out in all provinces in Indonesia. With the sampling technique using Two Stage Sampling, the sample in this study amounted to 46,230 samples with the characteristics of male and female school students aged 15-18 years. This study used secondary data obtained from the Health Research and Development Agency. The data analysis technique used is Chi Square analysis. The results showed that there was a significant positive relationship between physical activity and emotional mental disorders, and $\mathrm{Ha}$ is accepted. There is a relationship between physical activity and emotional mental health in Indonesia high school students in 2018.
\end{abstract}

Keywords: Phisical activity, emotional mental health.

\section{Introduction}

Health is often perceived from a physical point of view. Though healthy also means mental health. Unfortunately, mental health issues are still considered less important than physical health. Even though currently there is health insurance that offers protection related to mental health. The World Health Organization (WHO) said that young people, aka the millennial generation, are currently more susceptible to mental disorders. In Indonesia alone, the number of mental disorders among the population aged 15 years and over has increased from $6 \%$ in 2013 to $9.8 \%$ in 2018 [2]. Among Indonesian adolescents, there are many phenomena of students' inability to manage stress. The result will be tragic things such as running away and committing suicide, for example, 25 students committed suicide because they were declared not passing the exam [28], Elementary school students commit suicide because they get bad grades [29]. In this era of globalization, there are many challenges that must be faced by school age children or students in Indonesia in the form of pressures caused by various conditions in their surroundings.

Most of the sources of student pressure come from academic problems [7]. This pressure can arise from changes in learning demands from the previous period and from year to year. The Ministry of Education and Culture sets the graduation standard which is always increasing. In addition, the demand for the curriculum used in Indonesia is the 2013 curriculum, which requires students to be more active during Teaching and Learning Activities (KBM) and increase lesson hours so that students leave in the morning and return home in the afternoon, 
and maybe some students also take additional lessons. out of school. So they don't have time to do physical activity.

According to WHO (in Welis) physical activity is a body movement produced by skeletal muscles that requires energy expenditure. Changes in lifestyle towards a sedentary, namely a lifestyle that has less physical activity affect physical and mental health. The benefits in the health aspect are preventing obesity because by doing activities calorie burn will occur [20]. Physical exercise can increase attention and motivation, through increasing levels of dopamine and norepinephrine, thereby making a more positive mood, reducing anxiety, and increasing self-confidence [2]. Physical exercise can also increase serotonin [2]. Serotonin is the third monoamine neurotransmitter, also known as 5-HT, aka 5- hydroxytryptamine. The effects on behavior are complex. Serotonin plays a role in mood regulation, control of eating, sleeping, and wakefulness, as well as in pain regulation[21].

There are several factors that affect mental emotional health. There are two factors that affect mental health, namely internal and external factors [5]. These internal factors include personality, physical condition, development and maturity, psychological conditions, diversity, attitude to face life problems, meaningfulness of life, and balance in thinking. As for what includes external factors, among others, social, economic, political conditions, customs, environment, and so on. Furthermore, reveals that the two factors above[5], the most dominant are internal factors. The factor of peace of life, peace of mind or inner happiness does not depend much on external factors such as social, economic, political, customs, etc. However, it depends more on the way and attitude to deal with these factors. In the current condition of school children, they tend to rush in making decisions, such as wanting to end their own life because the daily test scores are unsatisfactory or doing negative things such as using narcotics because they do not pass the exam.

Research published in the American Journal of Psychiatry in 2018 that examined 22,000 Norwegian participants found a strong association between not exercising and depressive disorders. The results also showed that regular exercise could prevent depression by as much as $12 \%$, even with just one hour of physical activity a week [12].

Physical Activity

Physical activity as body movements produced by skeletal muscles that require energy expenditure, including activities performed while working, playing, doing household chores, traveling or activities involved in recreation. Physical activity can be planned, structured, repetitive, and aims to improve or maintain one or more components of physical fitness[31].

The right physical activity will spur the child's growth and development optimally. The benefits of physical activity for the child's emotional are:

Intellectual Development

Exercise is also beneficial for intellectual development. Sport also provides opportunities for children to move to express themselves, shout sounds according to the movements carried out, activate cognitive functions through symbolic roles, language development, and use of symbols at an early age, and develop strategic learning skills, make decisions, integrate information., and solve problems at later age development.

Emotional and Social Development

Physical education is useful for personal and social development which requires individual efforts to interact with others. The acquisition of desired social values such as cooperation, commitment, leadership, honesty as well as responsibility and tolerance need to be taught through participation in activity-based teaching. Enjoying physical activity will increase selfconfidence and social awareness. States that physical abilities are closely related to children's self-image. Children who have better physical abilities in sports will cause them to be 
appreciated by their peers [10]. Physical activity also provides an opportunity for release of emotional tension in appropriate ways. When participation is shown by students who are also supported by the environment,

Emotional Mental Health

Mental health is a condition in which an individual has a visible well-being that is able to realize his own potential, has the ability to cope with the pressures of normal life in various situations in life, is able to work productively and generously, and is able to contribute to his community. Furthermore, mental health problems often occur in the elderly, women, low levels of education, and lack of income [32]. stated that individuals aged 16 years and over and groups of students who experience harassment and condescending attitudes by their parents have more than twice the risk of experiencing mental emotional symptoms [16].

Framework of thinking

Physical activity is a body movement produced by skeletal muscles that requires energy expenditure. There are many benefits that can be obtained when doing regular physical activity, including in terms ofpsychic such as reducing stresss, increasing self-confidence, and building a sense of sportsmanship. Conversely, if a person is not moving enough, it causes various health problems, both physical and psychological. Based on the results of the study, high school aged high school children often experience mental emotional health disorders characterized by feelings of loneliness, worry, and suicidal thoughts. This may be due to the demands of a fairly long study time that is imposed on them, resulting in periodic accumulation of stress and lack of physical activity. Based on these thoughts, the authors are interested in investigating whether physical activity has a relationship with emotional mental health in high school students in Indonesia

\section{Methods}

This research is a type of correlation research. This study used a cross sectional design. In a cross-sectional study, the relationship between the independent variable (risk) and the dependent variable (effect) is sought by taking a momentary measurement.

The population in this study were all households in Indonesia based on the highest level of welfare and education completed by KRT (Head of Household) [2]. The sample is part of the number and characteristics of the population [26]. In this study, the sample used was household member with the characteristics of school work [2] aged 15-18 years who had male and female sex. The age range is the age group for high school students in Indonesia [27]

This study uses secondary data obtained from the Indonesian Health Research and Development Agency (Litbangkes). The data used in this study were physical activity data and mental emotional health disorders in high school students aged 15-18 years in Indonesia. Physical activity data were obtained from a modified Global Physical Activity Questionnaire (GPAQ) questionnaire from WHO. The description of physical activity behavior includes heavy and moderate physical activity in daily activities (combined at work / at home, leisure time and transportation) in the number of days per week and the number of minutes per day.

Strenuous physical activity is physical activity carried out for $\geq 3$ days / week and MET (Metabolic Energy Turnover) minute per week $\geq 1500$ (MET minute value for strenuous physical activity $=8$ ). MET is a unit of energy expenditure and is used to measure physical activity in minutes. MET minute is a unit used to measure the volume of an individual's physical 
activity. Moderate physical activity is physical activity that is carried out for $\geq 5$ days a week with an average length of activity $\geq 150$ minutes a week (or $\geq 30$ minutes per day).

\section{Results}

\subsection{Descriptive Analysis}

In this study, the data in question is data obtained using secondary data and data collection techniques using a questionnaire. This study uses two variables, the independent variable, namely physical activity, and the dependent variable, namely mental emotional health. The research data were obtained from 46,230 samples with the criteria of respondent age 15-18 years who have male and female sex. The age range is the age group for high school students in Indonesia.

Table 1 Descriptive Statistics

\begin{tabular}{|c|c|c|c|c|c|}
\hline \multicolumn{6}{|c|}{ Descriptive Statistical Analysis } \\
\hline & $\mathrm{N}$ & Min & Max & Mean & SD \\
\hline \multirow{2}{*}{$\begin{array}{l}\text { Physical Activity } \\
\text { Mental Health Problems }\end{array}$} & 46,230 & 1 & 2 & 1,524 & 0.499 \\
\hline & 46,230 & 1 & 2 & 1,909 & 0.288 \\
\hline Gender & 46,230 & 1 & 2 & 1,489 & 0.500 \\
\hline Age & 46,230 & 15 & 18 & 16,216 & 1,057 \\
\hline Valid N (listwise) & 46,230 & & & & \\
\hline
\end{tabular}

\subsection{Characteristics of Respondents}

Table 2. Gender Frequency Distribution

\begin{tabular}{llc}
\hline Category & Frequency & Percentage(\%) \\
\hline Man & 23,611 & 51.1 \\
Women & 22,619 & 48.9 \\
Total & 46,230 & 100 \\
\hline
\end{tabular}

The table above shows the gender. Based on the table above, it is known that 23,611 respondents $(51.1 \%)$ were male and 22,619 respondents $(48.9 \%)$ were female. Based on this information, it is known that most of the respondents are male. 
Table 3. Respondents' Age Frequency Distribution

\begin{tabular}{ccc}
\hline Category & Frequency & Percentage $(\%)$ \\
\hline 15 years & 15,053 & 32.6 \\
16 years & 13,002 & 28.1 \\
& 11.303 & 24.4 \\
17 years & 6,872 & 14.9 \\
18 years & 46,230 & 100 \\
\hline Total &
\end{tabular}

The average age of the respondents was 15 years old, with the youngest being 15 years old and the oldest being 18 years old. Most respondents are 15 years old.

\subsection{Univariate Analysis}

The results of the analysis were carried out to analyze the individual characteristic variables that existed descriptively using frequency distributions and proportions. Univariate analysis in this study was carried out on research variables which include: physical activity and mental emotional health.

Table 4. Physical Activity Frequency and Emotional Mental Health Distribution

\begin{tabular}{llll}
\hline Characteristics & Category & Frequency & Percentage $(\%)$ \\
\hline \multirow{2}{*}{ Physical Activity } & Active & 22,023 & 47.6 \\
& Less active & 24,207 & 52.4 \\
& Total & 46,230 & 100 \\
\hline \multirow{2}{*}{$\begin{array}{l}\text { Emonitional } \\
\text { Health }\end{array}$} & Mental & 4,207 & 9,1 \\
& Not & 42,023 & 90.9 \\
& Total & 46,230 & 100 \\
\hline
\end{tabular}

\subsection{Bivariate Analysis}

Analysis of the relationship between physical activity and mental emotional health can be seen in table 5.

Table 5. Cross Tabs

\begin{tabular}{lcccccc}
\hline \multicolumn{7}{c}{ Emotional Mental Health Disorders } \\
\hline \multicolumn{2}{c}{ Yes } & \multicolumn{2}{c}{ Not } & \multicolumn{2}{c}{ Total } \\
\hline Physical Activity & $\mathrm{N}$ & $\%$ & $\mathrm{~N}$ & $\%$ & $\mathrm{n}$ & $\%$ \\
Active & 2,127 & 4,6 & 19,896 & 43 & 22,023 & 47.6 \\
Less active & 2,080 & 4.5 & 22,127 & 47.9 & 24,207 & 52.4 \\
\hline
\end{tabular}


Based on the table above, it is known that respondents who did physical activity in the active category were 22,023 respondents (47.6\%). Of the 22,023 respondents, $2,127(4.6 \%)$ experienced mental emotional health problems. While the majority, namely 19,896 respondents (43\%) did not experience mental emotional health problems. Based on information that most respondents do not experience mental emotional health problems. After that, there were 24,207 respondents who did physical activity in the less active category $(52.4 \%)$. Of the 24,207 respondents, 2,080 respondents $(4.6 \%)$ experienced mental emotional health disorders. Meanwhile, most of 22,127 (47.9\%) did not experience mental emotional health problems. Based on information that most respondents do not experience mental emotional health problems.

So it can be concluded that respondents who are active in physical activity tend not to experience mental emotional disturbances, while respondents who are less active in physical activity tend not to experience mental emotional disorders.

The two groups of physical activity have the same conclusion, namely that most of them do not experience mental emotional health problems. Even so, there is a slight difference in the percentage of respondents who experience mental emotional health disorders.

To know for sure whether there is a relationship between physical activity and emotional mental health, a statistical test is needed. The statistical test used is the chi square test:

Table 6. Chi Square Test

\begin{tabular}{cccc}
\hline Statistics & Chi Square & $\mathrm{P}$ & $\begin{array}{c}\text { Kendall tau } \\
\text { correlation }\end{array}$ \\
\hline Score & 15,827 & 0,000 & 0.019 \\
\hline
\end{tabular}

\section{Discussion}

The results of statistical calculations obtained a value of $\chi 2$ of 15,827 and a probability value of 0,000 . The probability value is $<0.05$, which means that there is a significant relationship between physical activity and emotional mental health. In the previous explanation, it is not known whether the pattern of influence is positive or negative, because the two groups produced the same conclusion, namely respondents with active or active physical activity. less active are less likely to experience mental emotional health problems. But it turns out that the results of statistical tests show the effect of physical activity on mental emotional health. The pattern of the relationship can be seen from the sign of the Kendall tau test, if it is positive then the relationship is positive and vice versa. The results of the Kendall tau calculation obtained a correlation coefficient value of 0,019 which means that the closeness of the relationship is very weak with a coefficient value of $<0.25$. However, the value of the relationship is positive so that the relationship between physical activity and mental emotional health is positive. Positive relationship here means that the higher the respondent performs physical activity, the better the mental emotional health. 


\section{Conclusion}

Research on the relationship between physical activity and emotional mental health in high school students in 2018 in Indonesia has the following conclusions, namely that the physical activity of students is almost balanced between those who are active and less active, namely $47.6 \%$ of students are active in physical activities and the remaining $52.4 \%$ of students are less active in physical activity. Then most of the students did not experience mental emotional health problems, namely as much as $90.9 \%$. Meanwhile, the remaining $9.1 \%$ experienced mental emotional health problems. Then there is a significant positive relationship between physical activity and mental emotional disorders. This is evidenced by the chi square statistical test, the probability value is $<0.05$ and the Kendall tau test is obtained a value of $0.019>0$ (positive).

\section{References}

[1] Andriana, LM, \& Ashadi, K. (2019). The comparison of two types of exercise in the morning and night to the quality of sleep. Sportif: Journal of Learning Research, 5 (1).

[2] Ambardini, RL (2009). Physical Education And Academic Achievement: A Neuroscience Review. Indonesian Journal of Physical Education, 6 (April), 46-52. https://doi.org/10.21831/jpji.v6i1.432

[3] CDC. (2015). How much physical activity do children need? - Physical Activity. Retrieved June 18, 2017, from Centers for Disease Control and Prevention: https: //www.cdc.gov/physicalactivity/basics/children/

[4] CDC. (2015). Physical Activity and Health. Retrieved from Centers for Disease Control and Prevention: https: //www.cdc.gov/physicalactivity/basics/pahealth/index.htm

[5] Daradjat, Z. 2001. Mental Health. Jakarta: PT Toko Gunung Agung.

[6] Dugdill, L., Crone, D., \& Murphy, R. (2009). Physical Activity and Health Promotion: Evidencebased Approaches to Practice. Chichester: Wiley Blackwell. Accessed from https://books.google.co.id/books?id= RSS5AsWuS9cC \& printsec $=$ frontcover $\& \mathrm{hl}=\mathrm{id} \&$ source = gbs_atb \# v = onepag e \& q \& f = false $\mathrm{p}$

[7] Elias, H., Ping, WS, \& Abdullah, MC (2011). Stress and academic achievement among undergraduate students in Universiti Putra Malaysia. Procedia - Social and Behavioral Sciences, 29, 646-655.https://doi.org/10.1016/j.sbspro.2011.11.288

[8] Erwinanto, D. (2017). The relationship between the level of physical activity and physical fitness of class x students in the 2016/2017 academic year at SMK Muhammadiyah 1 Wates, Kulon Progo Regency, DIY. Unpublished undergraduate thesis. Yogyakarta State University, Yogyakarta. Farhan, Mohammad. 2017. Applied nonparametric statistics: theory, a case study with IBM SPSS. Jogjakarta: CV Andi offset.

[9] Feliciano, L., \& Gum, AM (2010). Mood disorders. Diagnostic Interviewing: Fourth Edition, 153176.https://doi.org/10.1007/978-1-4419-1320-3_8

[10] Gabbard, C. LeBlanc, B., \& Lovy, S. 1994. Physical education for children: Building the foundations. (2nd ed). Englewood Cliffs, NJ .: Prentice Hall.

[11] Hamrik, Z. et al. (2014). Physical activity and sedentary behavior in Czech adults: Results from the GPAQ study. European Journal of Sport Science. 14. Pg. 193-198.

[12] Harvey, SB, Overland, S., Hatch, SL, Wessely, S., Mykletun, A., \& Hotopf,

[13] Haskell, WL, \& Kiernan, M. (2000). Methodologic issues in measuring physical activity and physical fitness when evaluating the role of dietary supplements for physically active people. American Journal of Clinical Nutrition, 72 (2 SUPPL.). https://doi.org/10.1093/ajcn/72.2.541s

[14] Idaiani, S., \& Kristanto, AY (2007). Analysis of Symptoms of Indonesian Population Mental Emotional Disorders. 473-479.

[15] Idiani, S., \& Wahyuni, HS (2016). Association Between Mental Emotional Disorders and Hypertension among Indonesian. Media Litbangkes, 26, 137-140. 
[16] Momotani, H., \& Yamamoto, H. (2014). [Mental health problems]. Nihon Rinsho. Japanese Journal of Clinical Medicine, 72 (2), 288-292.

[17] Marini. (2006). factors that influence the incidence of depression in elderly at the Geriatric Clinic of Ciptomangunkusumo Hospital, 2006-2008. Thesis. UI.

[18] National Institute of Health. (2016). Benefits of Physical Activity. Retrieved from National Institute of Health: HTTps: //www.nhlbi.nih.gov/health/healthtopics / topics / phys / benefits

[19] Nichols, Beverly. 1994. Moving and learning: The elementary school physical education experience. 3rd ed. St. Louis: Mosby-Year, Book Inc.

[20] Nurcahyo, F. (2011). The Link Between Obesity and Physical Activity. Link Between Obesity and Physical Activity, VII (April), 87-96.

[21] Permono, JW, \& Kusristanti, C. (2017). Sports and Emotion Regulation: A Correlation Study of Official College Cadets (Ptk). Journal of Ulayat Psychology, 3 (2), 169.https://doi.org/10.24854/jpu22016-70

[22] Remschmidt, H., Nurcombe, B., Belfer, ML, Sartorius, N., \& Okasha, A. (2007). A Global Program for Child and Adolescent Mental Health: A Challenge in the New Millennium. The Mental Health of Children and Adolescents: An Area of Global Neglect, 111.https://doi.org/10.1002/9780470512555.ch1

[23] Sari, IAC, \& Purnawati, S. (2017). The prevalence of shift work sleep disorder among night shift workers in several franchises in South Denpasar. Udayana Medika E-Journal, 6 (7), 19.https://ojs.unud.ac.id/index.php/eum/article/view/33428

[24] Schoon, I. (2006). Risk and resilience: Adaptations in changing times. Risk and Resilience: Adaptations in Changing Times, January 2006, 1-222.https://doi.org/10.1017/CBO9780511490132

[25] Setyaji, DY, Prabandari, YS, \& Gunawan, IMA (2018). Physical activity with coronary heart disease in Indonesia. Indonesian Journal of Clinical Nutrition, 14 (3), 115.https://doi.org/10.22146/ijcn.26502

[26] Singh, A. \& Purohit, B. (2011). Evaluation of Global Physical Activity Question (GPAQ) among Healthy and Obese Health Professionals in Central India. Baltic Journal of Health and Physical Activity. 3. Pg. 34-43.

[27] Tambunan, Derwin. 2010. Differences in Mental Health in Gays in terms of Religious Behavior. Essay. Faculty of Psychology, University of North Sumatra.

[28] Manado Tribune. 2017. Got Bad Values, This boy committed suicide.https://manado.tribunnews.com/2017/12/12/dapat-nilai-jelekbocah-ini- $\quad$ suicide-his-lastmessage-makes-cry. (accessed July 25, 2020)

[29] Tribune News. 2019. 25 High School Students Suicide because they failed to pass the exam.https://manado.tribunnews.com/2019/05/04/25-siswa-sma- suicide-because-the-results-thetest-not-passed-there-is-one crash-self-to-train. (accessed July 25, 2020)

[30] WHO. A user's guide to the self reporting questionnaire. 1994.

[31] WHO. 2018. Physical Activity. https://www.who.int/news room / fact- sheets / detail / physicalactivity.

[32] WHO. (2001c). Atlas: mental health resources in the world. Geneva: World Health Organization. 